3

Public Media Service

in Mexico and Latin America

Recent Improvements and Future Challenges 



\title{
Public Service Media in Mexico and Latin America Recent Improvements and Future Challenges
}

\author{
José Antonio Brambila \\ University of Leeds, United Kingdom
}

\begin{abstract}
As in Latin America generally, public service media (PSM) has struggled in efforts for development in Mexico due to a lack of editorial independence, economic precariousness and absence of widespread availability as well as popularity. Nevertheless, Latin American social, political, economic and technological landscapes have changed significantly in the last two decades. In this context, the paper addresses the question of what this has meant for PSM development in the region. The study focuses on the case of Mexico, drawing on official data, interviews with experts, and providing specific examples of the situation in the country. This paper offers an overview and update of the state of PSM in Mexico and argues that despite challenges, problems and complications, improvements have been achieved and there is hope that development will continue.
\end{abstract}

Keywords: Public service media, new media policy, organizational adaptation, Latin America, media reform

José Antonio Brambila, School of Media and Communication, University of Leeds, Leeds, UK, LS2 9JT. Email: mejabr@leeds.ac.uk

Copyright (C) 2016 (José Antonio Brambila)

A. Rahman \& G. F. Lowe (Eds.), Public Service Media Initiatives in the Global South

(c) (i) $\odot$ Licensed under the Creative Commons Attribution-NonCommercial-NoDerivatives 4.0

Available at http://monographs.lib.sfu.ca

DOI: $10.21810 /$ sfulibrary.1.10 



\title{
Public Service Media in Mexico and Latin America Recent Improvements and Future Challenges
}

\author{
José Antonio Brambila \\ University of Leeds, United Kingdom
}

\section{History and Background}

The media model that Latin American countries have adopted has been very similar to the commercial-entertainment media project in the USA. It consists of private companies funded by both private and public advertisements, with high levels of media concentration and very few public media initiatives. In addition to this commercial approach, state intervention in broadcasting and communication industries aims to reinforce governmental control rather than promote democratic communications. In this context, public service media lacks financial resources and sufficient editorial independence, and has been concentrated in urban centers. More recently, there are also technological challenges in achieving digitalization (Waisbord \& Mastrini, 2015).

The history of broadcasting in Latin America began at the end of the 1920s with the first radio stations administered by government in the Dominican Republic (1928), Uruguay (1929), and Bolivia (1933). The first television channels were launched in Venezuela (1952) and Chile (1959) (Torres, 2015; Toussaint, 2010). Mexico launched radio in the 1930s (Radio Educación in 1931 and Radio UNAM in 1937), and television at the end of the 1950s (Once TV Mexico in 1959). As was the case for the majority of countries in Latin America, with a few notable exceptions of Colombian Consejo Nacional de Television in the eighties (Fox \& Anzola, 1988) and Televisión Nacional de Chile since the nineties (Fuenzalida, 2009) ${ }^{1}$, broadcasting was developed by governments with a propagandist logic to support either dictatorships or democratically-elected governments (typically populists or neoliberals), mainly the former (Arroyo et al., 2012).

Thus, broadcasting in Latin America began in the same period as elsewhere but took with an approach that was essentially government controlled and propaganda oriented, that is to say authoritarian in complexion. Although sometimes referred to as public media, especially by apologists, in more precise terms the history of broadcasting in the region reflects a strong orientation to state broadcasting.

1 With regards to the Colombian case, academics (Fox \& Anzola, 1988) have pointed out that Colombian public television has performed a relatively independent function for most of their life, especially because was constituted as a mixed system, in which the State owned the transmissions facilities, and time were allocated to private companies. On the other hand, the Chilean governmental broadcasting, TVN, suffered a profound political, legal and economic reforms during the first years of democratization in the 1990s, that transformed it from a propagandistic machine to a more transparent, diverse and truthful channel in the following years. The reform also included a new financial scheme (which allows TVN to elude governmental dependence and commercialize some contents), as well as a very successful programming offer, which maintain competitive rating with commercial channels (Fuenzalida, 2009). 


\section{What Does PSM Actually Mean in Mexico and Latin America?}

Despite the long history of broadcasting in the region, there is no consensus about what 'public media' means in Mexico, or in Latin America generally. According to the Argentine scholar Martín Becerra (2013), the distrust that governments created by handling everything related to broadcasting fueled alternative initiatives by proponents of a more democratic media system in civil society, largely activist citizens and intellectuals. Such would include two Brazilians, Luis Gonzaga Motta and Ubirajara da Silva, the Peruvian Rafael Rocangliolo, and the Mexicans Beatriz Solis and Aleida Calleja (2005), among others (Becerra, 2013). These and others embraced the idea of public media and encouraged developing independent, diverse and self-financed media (i.e. community media). This has been important to media and democracy development (and in their connection) in the region, despite financial and technical limitations. Although there are important differences, especially when thinking about institutional aspects, community media is congruent with Western ideals about public service media (Waisbord, 2013; Lugo-Ocando et alt. 2010).

The Venezuelan theorist, Antonio Pasquali, proposed in 1961 what is considered to be the first and most influential definition of public media in the region. For him, this means that media do not belong to private agents, are financed by government (i.e. public money), enjoy financial and editorial autonomy, operate under the supervision of an independent body appointed by government, and offer a universal and pluralistic range of services (Safar \& Pasquali, 2000). Although laudable, 50 years later public media remains very far from Pasquali's ideas (Waisbord \& Becerra, 2015). Nonetheless, Florence Toussaint ${ }^{2}$, a prominent Mexican scholar, argues that public media in Mexico (and this equally applies to most of Latin America) are public institutions with a rather long history and sense of permanence because they transcend each successive administration, are persistently financed by governments (even if not consistently), and offer alternative programing to commercial media ${ }^{3}$.

Thus, despite criticisms that are warranted, the picture is more nuanced than many critics from the West, mainly, have presumed. One also needs to be careful not to lump all of the diverse countries in the region into a common category, as if the situation for public media (indeed for media systems more generally) are undifferentiated. There are regional characteristics, of course, and the most pronounced of those are 1) the tradition of government control and interference, and 2) a (somewhat) countervailing commercial orientation. But there are also indications of a genuine interest in developing public media as a service for and to civil society. As we shall see, these tensions are highly evident in Mexico.

\section{Organization and Structure}

With a whimsical and discretionary history of granting licenses, the public media in Mexico comprise a complex and somewhat miscellaneous assortment of stations and channels that

2 (2015, September) Personal interview with author in Mexico City.

3 Even for Silvio Waisbord (2013), there exists historical terminological confusion between official, state and public media in the region. In this paper I refer to PSM as all media initiatives financed by the State, including the so-called state media, which is financed by the Judicial or Legislative powers. 
include public and private university initiatives, those launched by cultural interests with an artistic focus, and many of which program for children or indigenous peoples. They operate at diverse levels from the Federal to the regional to the local. And there are a lot of them altogether 596 stations (one third of Mexico's total number) with a combined estimated audience of 25 million people (Juárez Escalona, 2014). But Mexico's public media does not represent robust competition for private media, partly because as a whole they do not cover all of the national territory or reach a majority of Mexicans - about 122 million in total. These stations are not up to speed with digital media development and from time-to-time some have been associated with corruption scandals and administration wrongdoing 4 . As in the rest of Latin America (again with the exception of TVN in Chile), government subsidies are their primary source of income.

The problems in providing a genuine public service alternative to the dominant players in Mexico's highly commercial media system are keyed not only to the lack of any real PSM legacies here, but also to fragmentation, limitations in reach, poor infrastructure and incompetent management - i.e., a mixture of structural, technical, resource-related and managerial features. This suggests that future development will require addressing - indeed, redressing - each and all of these features.

In Mexico public radio includes two national networks (IMER and Radio Educación), fifty University stations (such as Radio UNAM, Radio $U$ de $G$ and Ibero90.9), sixteen state government stations at local level, twenty-one indigenous stations (including Sistema de Radiodifusoras Culturales Indigenas) and a single international digital radio station (Radio México Internacional). Public television has four national channels that broadcast from Mexico City (Once TV México, Canal 22, Educa TV y Una Voz con Todos); four University stations (in the states of Sonora, Nuevo Leon, Guadalajara and Mexico City); twenty-four state television stations and two digital channels for the Judicial and Legislative authorities. Mexican government also runs one information agency (Notimex), with correspondents in many Mexican states and abroad (Hernández López, 2014; Gómez y Sosa Plata, 2012).

Thus, there is no shortage of channels that can secure the public interest in Mexico, but the observed problems make the system quite problematic. There is cause for some optimism, however, because change is in the wind.

\section{New Regulatory Framework, New Opportunities}

After half a century of a legal impasse in the broadcasting sector, a new institutional design emerged from the 2014 bill on telecommunications. Approved by the Mexican state (LSPREM, 2014), it has created opportunities for public broadcasters to enhance and consolidate core public service values. Importantly, this new regulatory framework has finally and formally recognized that media financed by the government are not official media but media for the public, that is to say independent. This is one of the historic civil society demands.

${ }^{4}$ Just in the last two years there have been corruption scandals in the most important Mexican public channels, including but not restricted to the following TV channels: Canal 22 (Villamil, 2015), Canal Judicial (Aranda, 2015) and Once Tv México (Hernández, 2014). 
Another important step forward to establishing an independent and impartial public media service in this reform package is the mandatory adoption of internal regulatory bodies to regulate content (Sosa Plata, 2014), including especially the code of ethics (Baydar, 2008, p. 22) and a news ombudsman (Maurus, 2008, p. 71). Regarding the provision of news, recent empirical evidence (Brambila, 2014) demonstrates that the adoption of internal checkpoints in Mexican public media contributes to providing political news coverage characterized by veracity and balance, and importantly avoiding sensationalism and tabloidization (Hallin, 2000), one of the most common features in news framing among the region.

Although the incorporation of these internal checkpoints is a broad practice among public media (Once TV México and Canal 22 in 2007; Radio Educacion and the IMER in 2008 and 2009, respectively; Canal del Congreso in 2014 and SRP in 2015), the former Ombudsman for IMER and current Ombudsman at Once TV Mexico, Felipe Lopez Veneroni ${ }^{5}$, said the mandatory implementation of self-regulatory bodies has been a very tough task - especially at the local level - and there is still a lot to do. While the public increasingly acknowledge these internal bodies, many people don't know about them and quite a few see the ombudsman as a governmental censor.

\section{The New Mexican Public Broadcaster: A True Public Media Agency?}

The reform also led to the development of the Sistema Público de Radiodifusion del Estado Mexicano (SPR) ${ }^{6}$, an agency that attempts to group, coordinate and help in the transition to 'digital' across national public television networks (Once TV México, Canal 22, TV UNAM, Canal del Congreso, Canal Judicial and the recently created Una Voz Para Todos). But Toussaint ${ }^{7}$ believes the incorporation of these institutions into the SPR network or system represents a potentially damaging association with the political regime because this body depends upon the Executive branch of government. The new basis provides SPR with a civil council (the Consejo Ciudadano), that is composed of nine civil society members appointed by two-thirds of the Upper Chamber of Congress. But this group only has the authority to issue opinions, and their decisions are not binding. So Mexico is making an uneven progress here.

From the technical point of view, SPR attempts to fulfil one of the traditional goals of a public media service: Universality (McQuail, 1992). This has been a long-term problem. There are still regions that cannot access public media, national channels (for this more than a third of the country's territory) or even local public media. The northern state of Tamaulipas ${ }^{8}$ is one such region. SPR attempts to achieve the goal through ownership of a nationwide network of transmitters operated as a public television network. The goal is to improve the free-to-air availability of public channels throughout Mexico. Currently, SPR's transmitter network currently broadcasts from 14 of the 32 states and reaches $56 \%$ of the Mexican population, which indicates the scale of the challenge that remains.

${ }^{5}$ (2015, September) Personal interview with author in Mexico City.

${ }^{6}$ In July 2010, the Mexican government established by decree the Organismo Promotor de Medios Audiovisuales (OPMA): a mission to ensure that more Mexicans could receive a wider range of public television channels. Four years later, the Mexican telecommunications reform transformed OPMA into the SPR, which allowed the expansion and greater co-ordination of public broadcasting across the country.

7 (2015, September) Personal interview with author in Mexico City.

8 (2015, September) Personal interview with author in Mexico City. 


\section{Between Financial Limitations and Budget Cuts}

The 2014 reform contemplates limits on advertising for public media airtime (not more than 5 seconds per advert) and ensures little sponsorship would be received. This is quite problematic and accounts for the lack of personnel, material and new technology. This limitation prevents these public service providers from gaining additional resources and restricts them to dependence on the government budget. This explains the chronic problem in successive budget cuts and re-assignations that damage their ability to make long-term plans of operation and programming, and to pursue digitalization.

For example, in recent years a notable Federal budget cut for public media as imposed despite the fact that the transition to a fully digital system was scheduled for 2016 and is still not finalized. In comparison to the previous administration (see, Figure 1), which increased the budget for public radio and television (Radio Educación, IMER, Once TV México and Canal 22) by up to $100 \%$, since 2012 the budget has not kept up with technical and operational requirements (Sosa Plata, 2014b). Even worse, in the past three years the government has reduced Canal 22's subsidy, which resulted in lay-offs (Animal Politico, 2015) and programming cuts at a scale that is without precedent (Canal 22, 2015). Fired media workers claims governmental censorship in this case.

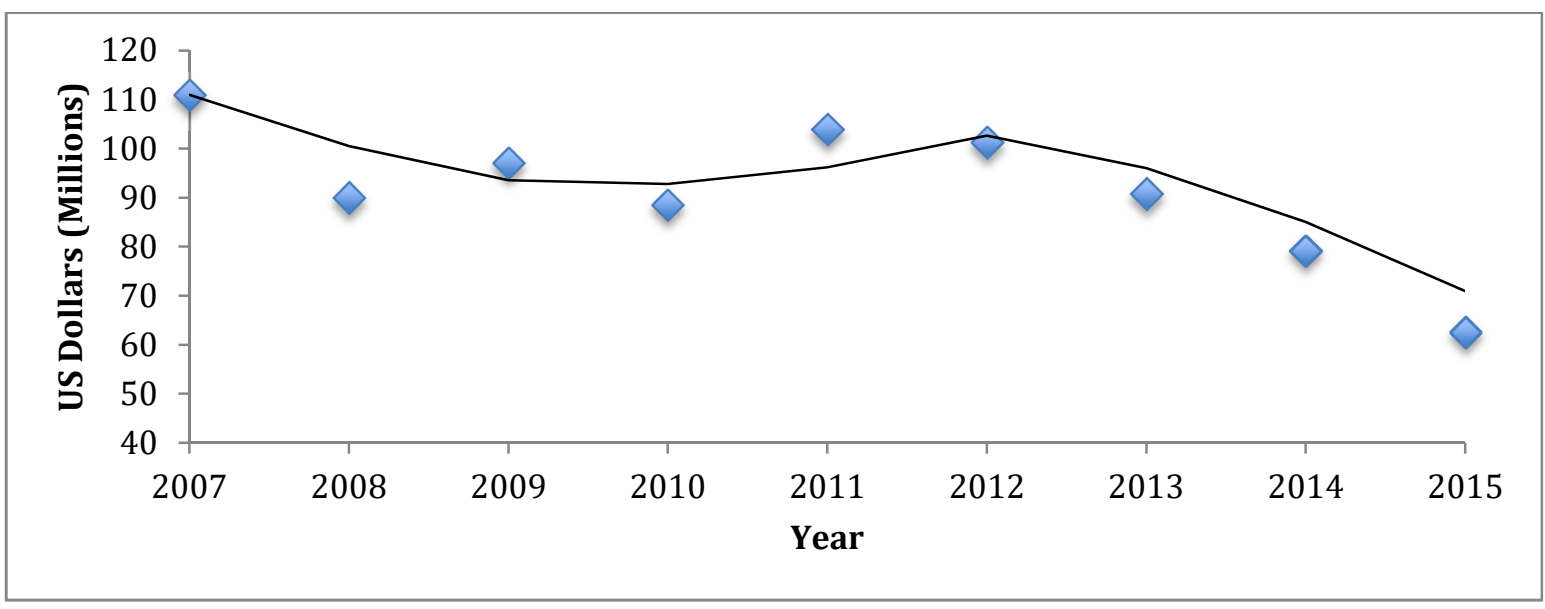

Figure 1. Public media service budget (from 2007 to 2015) (Constantans US Dollars) (source: Public Budget (Secretaria de Hacienda y Credito Publico 2007-2015). Federal budget for Once TV México, Canal 22, SPR, Dirección General Educativa, IMER and Radio Educación).

In contrast to the reduction in the public media subsidy, during the first two years of the current administration (2013 and 2014), for each US dollar the Federal government allocated to public media the President's office spent five US dollars on private mass media and advertisements (Fundar and Article 19, 2015). So although PSM is supported in principle, in practice it is kept weak and remains vulnerable to budgetary manipulation. 


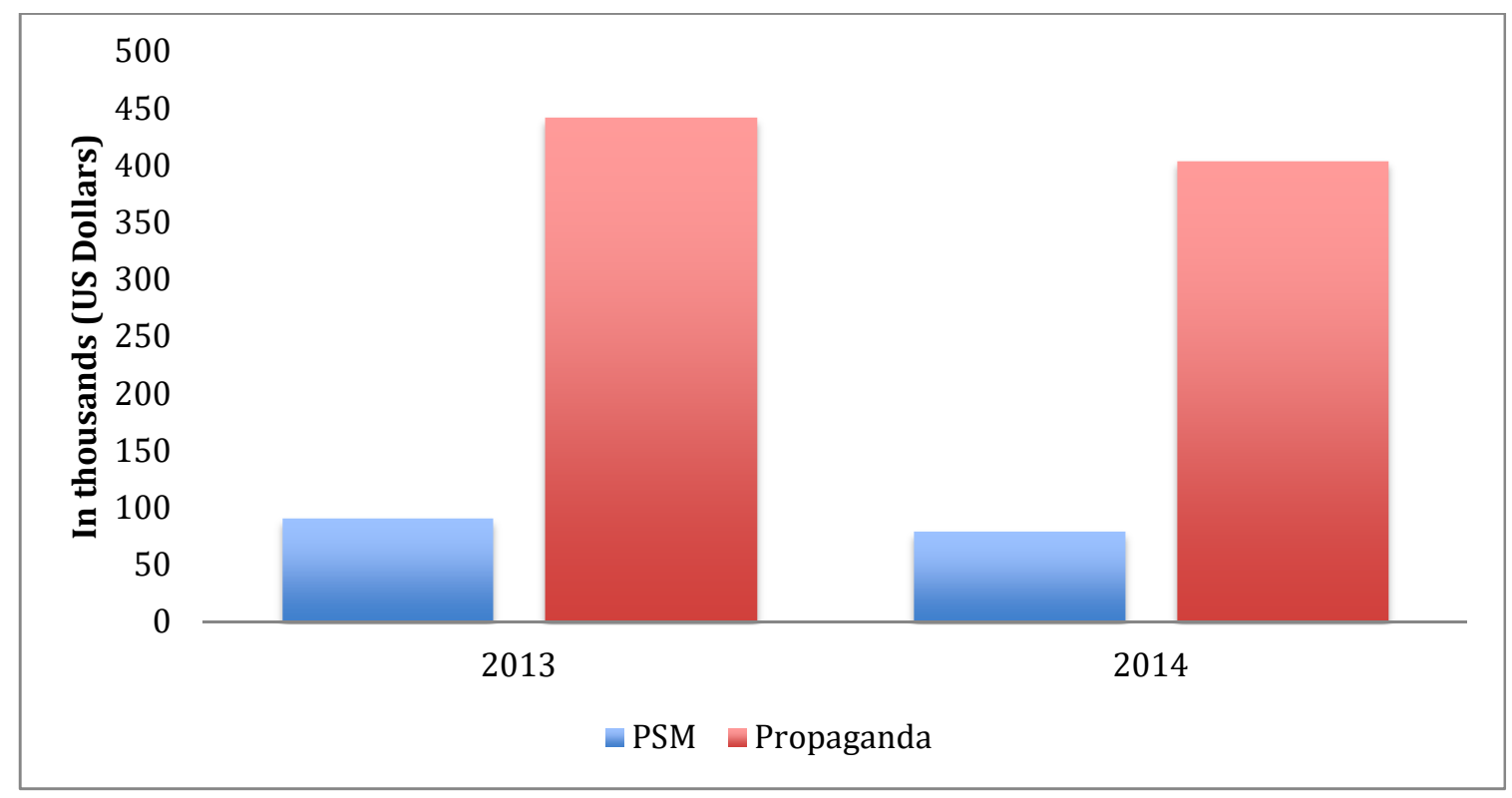

Figure 2. PSM Budget VS federal government's expenditures on official advertisement, 20132014(Constantans US Dollars) (source: Fundar and Article 19 (2015) and Secretaria de Hacienda y Credito Publico). * PSM budget only includes SPR, Once TV Mexico, Radio Educación, Notimex, Direccion General de TV Educativa and IMER.

\section{PSM: State of the Art and Digital Transition}

In this section of the chapter we examine the characteristics and performance of public media in Mexico, highlighting advances so far accomplished and limitations to be overcome.

\section{Public Radio}

About $40 \%$ of Mexicans think public radio is an independent source of information that provides useful services for education and cultural life (Parametría, 2015a). Given the fact that public media is not a legacy approach here, and the heritage of state-run control that understandable breeds suspicion, this suggests hopeful promise for growing popular support. Despite the already noted limitations, the two primary national public networks are largely fulfilling these expectations.

IMER (Mexican Radio Institute) is the most successful public radio network in Mexico. They have 20 stations and an audience of 20 million, especially concentrated in and around Mexico City (Rosas, 2012). Of course success is relative. In fact, only 30\% of Mexicans have heard of IMER, that is still nearly one-third and this audience recognizes the Institute as a source for diversity of information and topics, and an alternative range of music - largely Jazz, Blues and variations of Rock (Parametría, 2015a). With 30 years of experience, IMER is able to sell expertise in production and engineering services as an alternative form of funding. By 2012, IMER became the first radio network in Mexico to be fully digitalized (Rosas, 2012). IMER's budget was USD 10 million in 2015. But IMER and the second important national network, treated next, recent years faced declines in resources that are fairly sharp. 


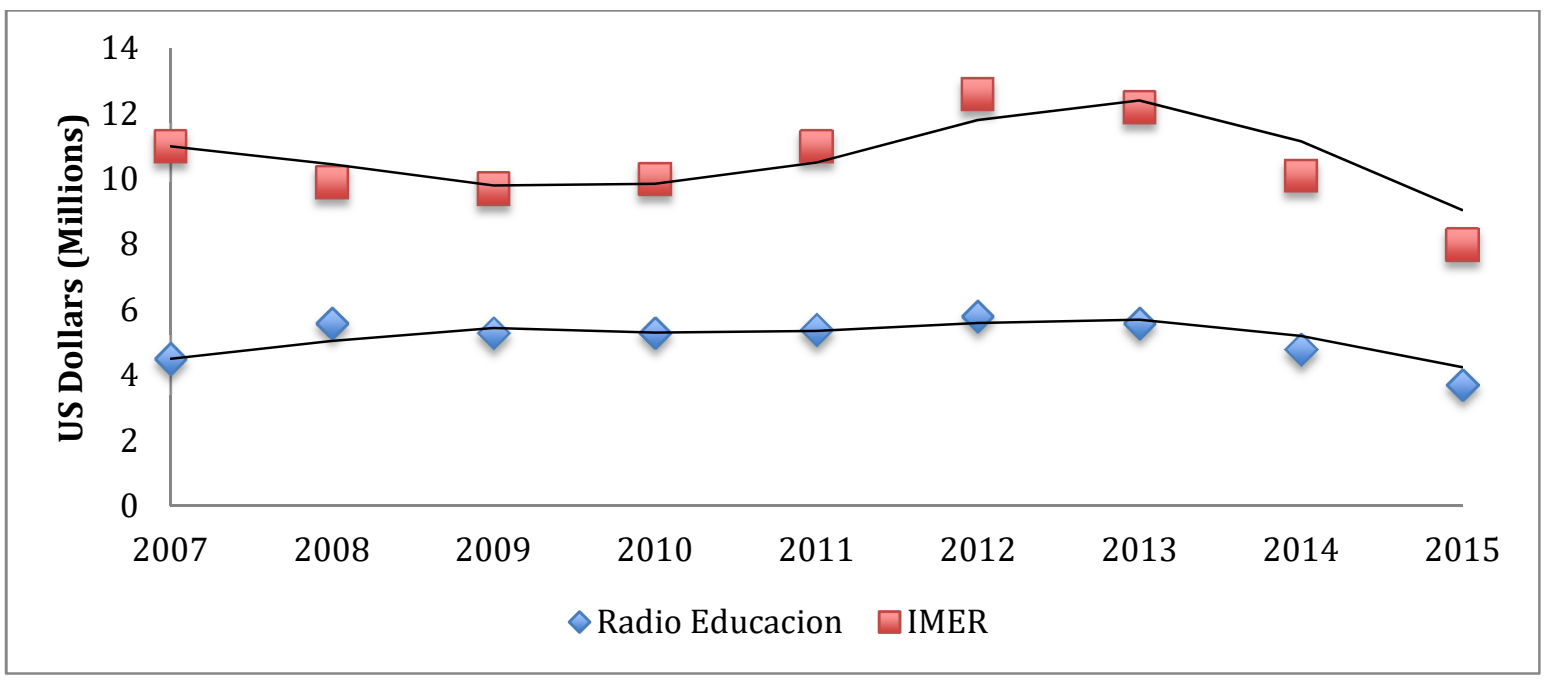

Figure 3. Radio Educación and IMER annual budgets 2007 - 2015 (Constantans US Dollars) (source: Secretaria de Hacienda y Credito Publico 2007-2015).

Radio Educación provides educational programming for Mexico City and half of the states in the country. The network produces audio books on their website and more than five thousand programs a year. It also broadcasts to the wider region via satellite, as far as the northern region of South America and the southern region of the United States. This organization has more than 85 years of experience and, since 2010, has been digitalizing their abundant archive of documentaries (Conaculta, 2010). In 2015 the Radio Educación budget was USD 5 million - which means they are doing a lot with a little. That indicates commitment to public service ideals, and importantly also an operation that is fairly efficient and certainly productive.

\section{Terrestrial TV Channels}

Since their establishment in 1959 and 1993 respectively, Once TV México (Eleven TV) and Canal 22 (Channel 22) have been recognized as national territorial channels with public service vocations (Navarro and Amezquita, 2007). Both channels are broadcast digitally from Mexico City and have a strong presence on the web, largely through the use of social media (Facebook and Twitter) and their YouTube channels (Brambila and Juárez, 2015).

Administrated by IPN (National Polytechnic Institute), a prestigious public university in Mexico City, Once TV México was the first university channel on the continent and is the most recognized public media operator in Mexico (Parametría, 2015b), with a potential audience of 70 million people (Once TV México, 2015), although it attracts just a few portion of the potential audience and reach has been declining. Despite lower audience levels (Gomez and Sosa Plata, 2011), Once TV México produces more than 75 per cent of its content, including educational programming and high quality children's programs (for this they have received international prizes). The Channel also produces news and editorial programs that represent a diversity of viewpoints. Currently, the channel broadcasts in High Definition Quality and had 
4.5 million visits to their Internet site in 2014. In 2015 they launched Once TV Niños, the first digital terrestrial channel completely dedicated to children's programming (Once TV México, 2015). In 2015 Once TV Mexico budget was USD 36 million. Given the content characteristics, the organization clearly demonstrates keen commitment to public service values and mission. But the decline is worrying.

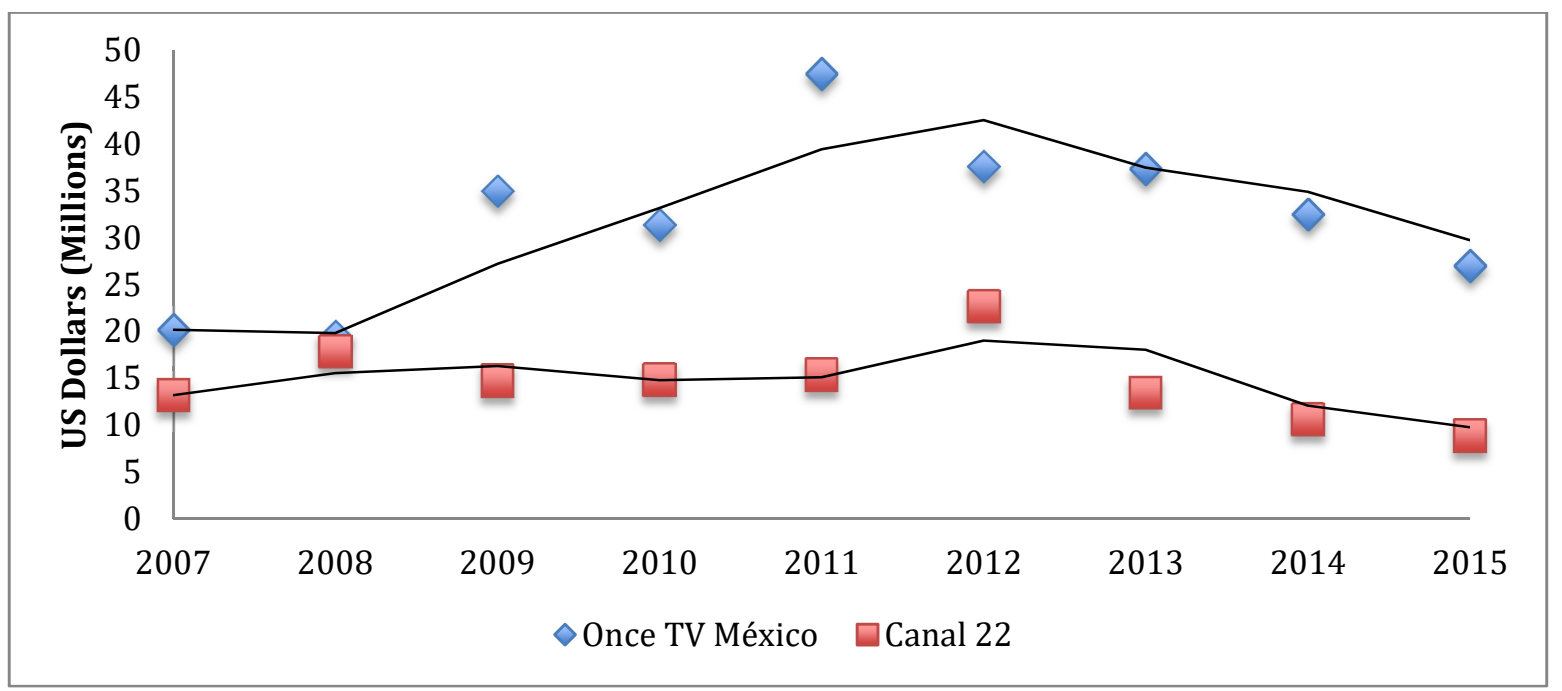

Figure 4. Once TV Mexico and Canal 22 annual budgets 2007 - 2015 (Constantans US Dollars) (source: Secretaria de Hacienda y Credito Publico 2007-2015).

Since it was founded in 1993, Canal 22, which belongs to the CONACULTA (National Council for Culture and the Arts), has promoted Fine Arts and Haute Couture, as well as native and popular culture. ${ }^{9}$ It has a potential audience of 36 million people, mostly in the metropolitan area of Mexico City (Conaculta, 2011a). Its programming offers cultural news, concerts, plays, art films, documentaries and cultural television series from international networks that include the BBC and TV Española. Through 2014, Canal 22 increased its production output by 50 percent (Conaculta, 2012) and made successful programs, such as the reality show Opera Prima en Movimiento, that captured one of the biggest audience ever for public television in Mexico - about half million people followed the reality show (Conaculta, 2011b). Canal 22's budget in 2015 was USD 12 million. Again, the channel fulfils an essential set of public service functions related to culture and the arts, but its resources have similarly been in decline in recent years.

\section{Digital Terrestrial Television (DTT)}

At the beginning of the 21st century, three digital terrestrial channels emerged that would escape the orbit of control by the Executive branch of government: TV UNAM (2015), Canal

${ }^{9}$ Since December 2015 a constitutional reform transformed CONACULTA into the Secretariat of Culture, the governmental department responsible for Mexico's cultural policy. 
del Congreso (2000) and Canal del Poder Judicial (2006). The first is administrated by UNAM (National Autonomous University of Mexico), which has autonomy over its budget and management. The others (Canal del Congreso and Canal del Poder Judicial) are managed by the Legislative and Judicial powers, respectively. All three transmit from Mexico City and each of them reaches 18 million homes through paid television service. In the near future these channels will transmit free-to-air digital signals (Canal del Congreso already does), which will represent a potential audience of between 18 to 24 million people (El Universal, 2015).

In its first 10 years, TV UNAM has distinguished itself by offering a diversity of scientific, cultural and educational programs. UNAM has its own productions and also international agreements with Arte in France, Canal Encuentro in Argentina and TV Española in Spain (Yglesias y Velazquez, 2015). Despite receiving 170 national and international rewards, its budget has been reduced in the past few years.

Due to the fact that the Congress and Supreme Court of Justice (SCJN) were under the control of the Executive and the one party system during the PRI dictatorship (1928-2000), launching the Congress and Judicial channels represents efforts to grow transparency and accountability. Inspired by the BBC's Paralamento and TV Senado of Brazil, Canal del Congresso (Congress Channel) emerged 15 years ago. It transmits live sessions from both the Senate and the House of Representatives, forums and parliament workshops, as well as productions (news and analysis content) linked to the agenda of congress. Canal Judicial (Judicial Channel), on the other hand, transmits SCJN sessions, analysis and news programs dedicated only to this government agency, as well as the international programs of the German public broadcaster, Deutche Welle.

Despite the rapid growth of DTT channels in Mexico, one of the most important obstacles in the near future is the low penetration of digital receivers in the country. According to official source (Inegi, 2014), digital technology is available to no more than 21 percent of the population, with most of those viewers concentrated in urban centers (Mexico City) or bordercities (Tijuana). This suggests a digital divide in media quite generally in Mexico, which is especially problematic for public media given the intentions to provide a universal service. The problem needs to be remedied, but that is unlikely so long as budgets are being cut and support is lagging.

\section{Local Public Media}

Like the German and Colombian models of public broadcasting, the Mexican model also favors decentralization and regionalization of public media initiatives. Although the first regional public radio and television networks started in the 1950s and 1960s (in the southern states of the country), the great majority of the 32 states in Mexico acquired frequencies in the 1980s and 1990s. The growth in TV happened mainly in the 1980s and levelled off in the 1990s, while radio growth has been more cumulative in nature (see Tables 5 and 6 below). 


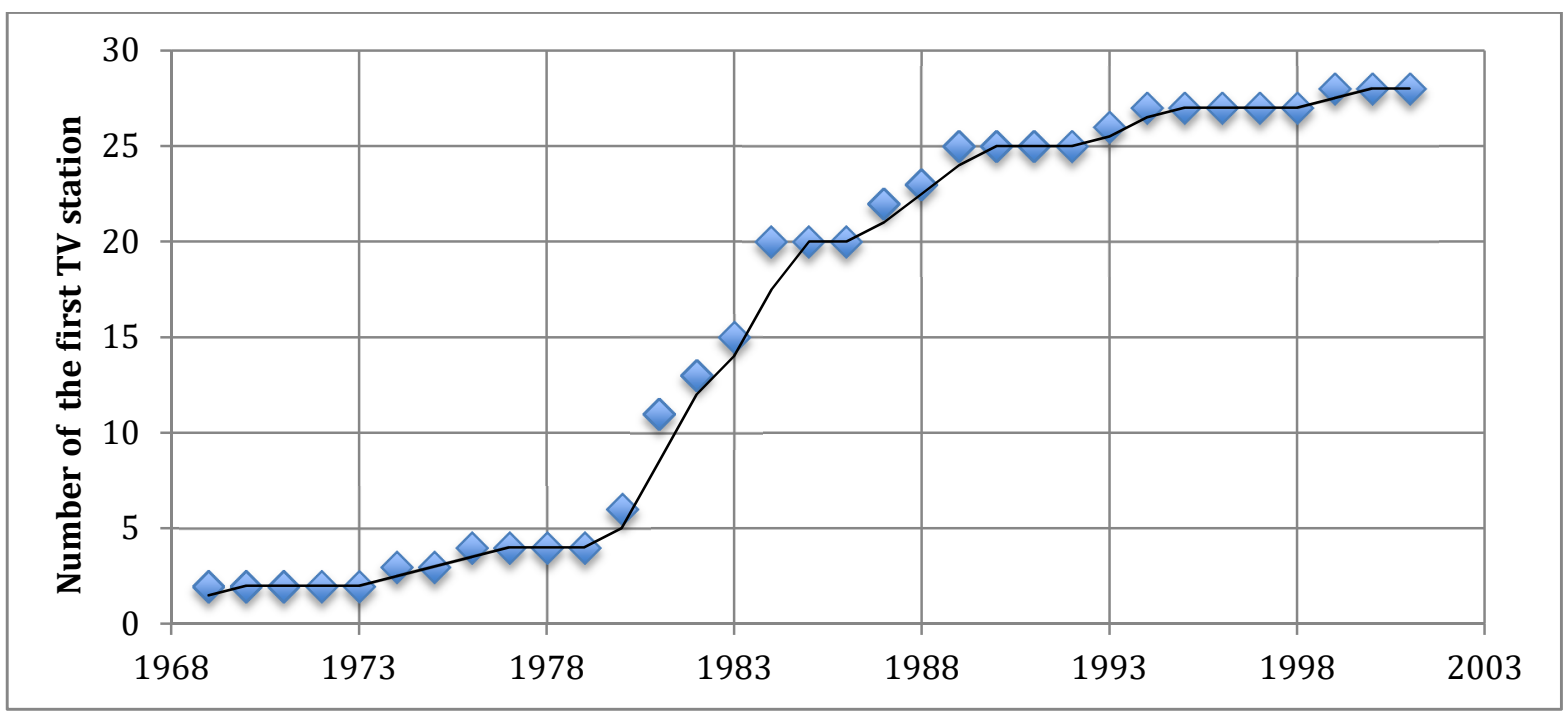

Figure 5. Mexican states with TV public stations per year of origin (1969-2001) [source: Toussaint (2009b), Ortega (2006) and Rebeil (1988)].

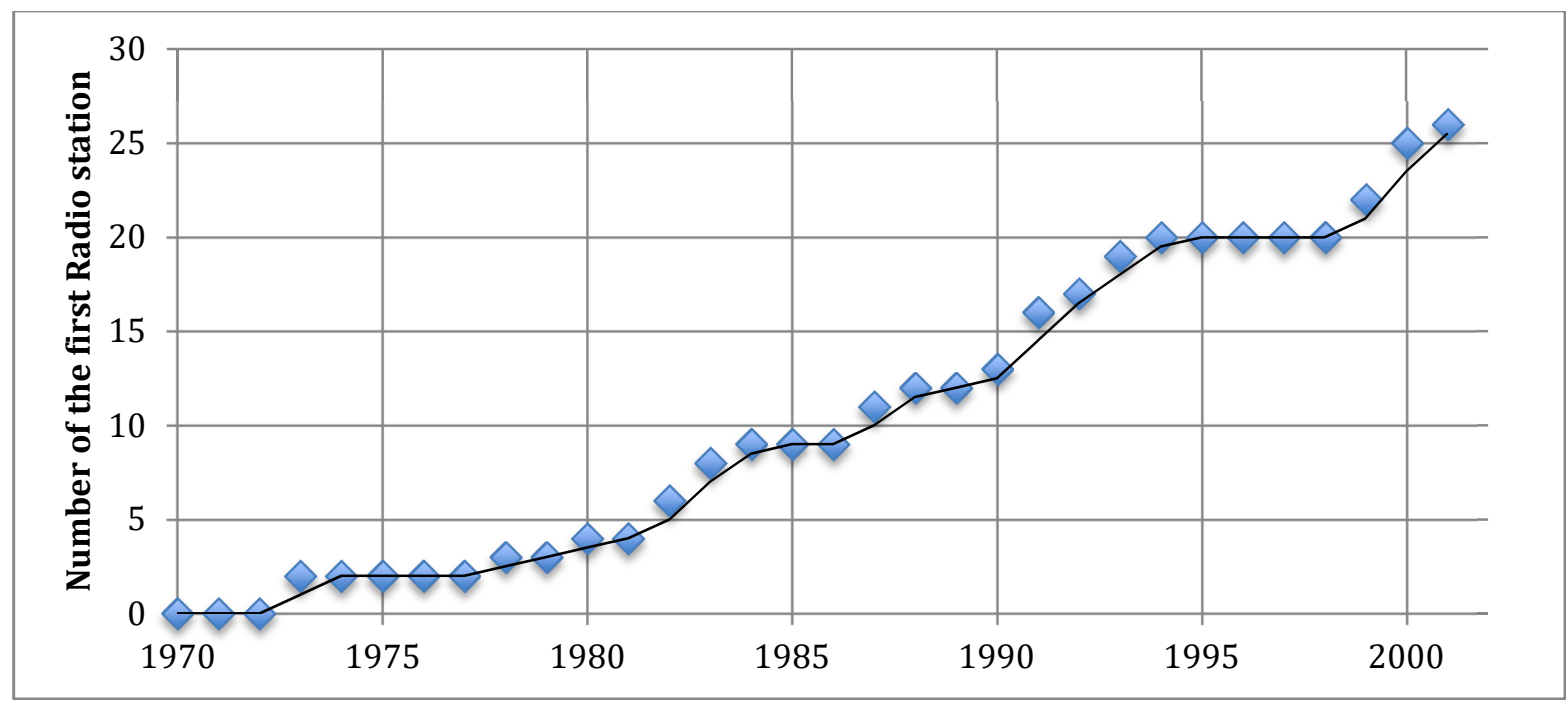

Figure 6. Mexican states with public radio stations per year of origin (1972-2001) [source: Toussaint (2009b), Ortega (2006) and Rebeil (1988)].

Nowadays, local public media is handled in 25 more or less separate systems for local and regional broadcasting. The financing for these systems is discretionary and depends on the will of the local incumbent (Toussaint, 2007). According to official information, half of the 25 systems operate with a budget between USD 0.5 and 3.5 million annually (for 2014 and 2015). A few are economically stronger (from Mexico City, Veracruz, Puebla and State of Mexico), with between USD 6 and 12 million per year.

Although these stations transmit national and international public media programming and produce content that supports pre-Hispanic culture and native traditions, according to 
Toussaint ${ }^{10}$ practically all of them operate under the editorial controls of the local incumbent. During election periods these stations are used as propaganda tools by the current administrations (Hughes and Lawson, 2004). Likewise at the Federal level, the lack of resources, problems with corruption and short-term planning hold back public broadcasters from developing with the latest technology and building digitalization. With only one year until the 2016 analogue blackout, the network of RED México (Cultural and Educational TV and Radio Networking), which co-ordinates the majority of local public initiatives, has announced that 29 of the 57 members require a massive intervention in order to transmit digitally, or they could disappear (Martinez, 2015). Nowadays, only a few public systems broadcast in digital, including but not restricted to Mexico City and the states of Oaxaca, Nuevo León and State of Mexico.

\section{Assessment and Recommendations}

In Mexico, as in Latin America generally, PSM faces similar challenges in the shadow of the mercantilist-broadcasting project (Arroyo et al., 2012), struggling for financial resources and editorial autonomy (Waisbord, 2013), and coping with uncertainty in finding their place in the emerging digital environment (Mastrini, 2013). Of course each country in the region has unique dynamics and a particular history, but much is quite similar as well.

Latin America is a region where broadcasting has been developed partly as a commercial project and this is an important factor in explaining the poor performance of public media initiatives. Latin American commercial houses are powerful (the Clarin in Argentina, Globo in Brazil, Grupo Santo Domingo in Colombia, Televisa and TV Azteca in Mexico). Media tycoons have hoarded concessions, and protect their shares of audiences and advertising with the help and collusion of Latin American governments (Guerrero \& Márquez, 2014). This situation has remained the same even in countries that have carried out media reforms in efforts to limit problems in media concentration (Waisbord \& Becerra, 2015).

In Mexico, the commercial tycoons (such as billionaire Carlos Slim, and TV barons Emilio Azcárraga Jean and Raul Salinas Pliego) control one of the most concentrated media markets in the hemisphere (Huerta-Wong \& Gómez, 2013). They have been active in preventing any attempt to give more legal tools and administrative faculties to PSM, especially efforts to commercialize airtime or garner sponsorships. In short, they work hard to limit competition. In the Latin American region, only the Chilean TVN (and the Colombian mixed system) have a legal guarantee to self-finance, which has allowed economic freedom and resulted in better audience ratings, sometimes better than commercial initiatives (Mastrini, 2013).

Besides living at the shadow of commercial broadcasting and the economic uncertainty, public media has suffered from poor management and a lack of editorial autonomy. On various occasions the President of the Republic has personally intervened and infringed on press freedom. And what can happen from the top happens quite a lot more moving down the political pyramid of power.

10 (2015, September) Personal interview with author in Mexico City. 
In recent years, many Left wing Latin American governments (Venezuela, Ecuador, and Bolivia) have reinforced the structure of public service media (Arroyo et al., 2012; Waisbord, 2013), although populism is a persistent problem that calls into serious question the degrees to which this is actually 'public service' versus state interest. However, according to Waisbord (2013) public media in these countries has diversified content, offers information that is absent in commercial channels, and is expanding the presence of minority groups (e.g. indigenous minorities) who have previously lacked access. So, again, the picture is more nuanced than sometimes thought.

Learning from the Chilean and Brazilian experiences (Arroyo et al, 2012; Fuenzalida, 2009), Mexican experts such as Florence Toussaint and Felipe Lopez Veneroni ${ }^{11}$ propose giving the state institutions full constitutional autonomy (as they have been given to the central Bank and the electoral body) so they could decide on their internal resources and selfadministration without governmental intervention. Thus far, however, the prospects are highly uncertain at best - and seemingly improbable due to the vested self-interests of commercial media and the chronic misuse of broadcasting for government propaganda, which benefits from keeping these operations dependent and thereby weak.

So far, Mexican experience shows that even when exist true commitment with public service provision from civil society and political elites, it becomes really hard to overcome inertial forces coming from the past (what Douglas North calls path dependence), which are embedded in the structures and practices that remind from the authoritarian period. In that sense, the most recently media reform approved in the country and the raised of the SPR in 2015 constituted some steps in the right direction, especially to ensure a more plural and transparent media service in the country. But, as I discusses above, there is a very long pathway to follow in order to endow Mexican public media with the economical and institutional provisions need it to fulfil their duty in the long-term.

At the end, Mexican and Latin American experience demonstrate that public service institutions did not travel from the West to the Global South, quiet to the contrary, they emerged in a very complex mix of values, ideas, experiences and necessities, which configured its features and determinate its functions. Nevertheless, novel institutional reforms and the right incentives to develop public media initiatives (in Brazil, Chile, Colombia or Mexico) may indeed contribute to establishing a true and genuine public service media within the region.

11 (2015, September) Personal interviews with author in Mexico City. 


\section{References}

Animal Político (2015, June 22). A 22 años de su creación, Canal 22 censura el periodismo de investigación, acusan trabajadores. Retrieved from http://goo.gl/tHuJQ2

Aranda, J. (2015, March 13). La PGR intervino en el Canal Judicial porque se halló polvo similar a cocaína. La Jornada. Retrieved from http://goo.gl/oMB2TB

Arroyo, L., Becerra, M., García, A., \& Santamaría, O. (2013). Cajas mágicas: el rena- cimiento de la tv pública en América Latina. Madrid: Tecnos, World Bank, UNDP and FIIAPP.

Baydar, Y. (2008). Setting up a Journalism code of ethics. In Haraszti, M. (Ed.), The media selfregulation guidebook. All questions and answers. Vienna: Organization for Security and Cooperation in Europe.

Brambila J. A., \& Juárez, J. (2015, July 15). Re-thinking PSM in Contemporary Mexico. Paper prepared for delivery at the International Association for Media and Communication Research Annual Conference, Montreal, Canada.

Brambila, J. A. (2014, August 28). PSM in New Democracies: Making News for Democracy in Latin America and Mexico. Paper prepared for delivery at Re-Visionary Interpretations of the Public Service Broadcasting (RIPE) bi-annual conference, Keio University, Japan.

Canal 22 (2015, July 22). Canal 22 hace público los recortes a sus producciones, Canal 22. Retrieved from Canal 22 http://goo.gl/6vhng9

Comisión Federal de Telecomunicaciones (2011, September). Estudio del mercado de servicios de televisión abierta en México. México: Cofetel. Retrieved from Cofetel http://goo.gl/vKn3wI

Consejo Nacional para la Cultura y las Artes de México (2010, April 20). Radio Educación emprende su renovación y fortalecimiento. Retrieved from CONACULTA http://goo.gl/lnxmBW

Consejo Nacional para la Cultura y las Artes de México (2011a, December 27). Avanza Canal 22 en cobertura y calidad de su señal durante 2011.

Consejo Nacional para la Cultura y las Artes de México (2011b, June 1st). Ópera Prima en Movimiento contó con la respuesta de los televidentes del Canal 22. Retrieved from CONACULTA http://goo.gl/S2XJ6H

El Universal (2015, August 5). Debuta hoy el Canal del Congreso en Tv abierta. Retrieved from http://goo.gl/mJdtHF

Fox, E., \& Anzola, P. (1988). Politics and regional television in Colombia. In E. Fox (Ed.), Media and politics in Latin America: The Struggle for Democracy. Beverly Hills: Sage.

Fuenzalida, V. (2009). Nuevas tendencias de la Televisión Pública en América Latina. In Televisión pública: Experiencias de Alemania y Latinoamérica. Buenos Aires: Konrad Adenauer Stiftung.

Fundar and Article 19 (2015). Libertad de expresión en venta. Acceso a la información y censura indirecta en publicidad official. Mexico City: Fundar and Article 19.

Gómez R., \& Sosa Plata G. (2012). Mapping digital media: Mexico. Open Society Foundations. Retrieved from https://goo.gl/ebSpGF

Guerrero M. A., \& Ma' rquez, M. (2014). Media systems and communication policies in Latin America. London: Palgrave, [kinlde edition]. Retrieved from Amazon.com

Hallin, D. C. (2000). La Nota Roja. In Tabloid tales: Global debates over media standards (C. Sparks and $J$ Tulloch, eds.), Rowman \& Littlefield Publishers. 
Hernández López, R. (2014, December 1st). Medios públicos mendigos. La Jornada San Luis. Retrieved from http://goo.gl/PvpQ6k

Hernández, L. G. (2014, May 18). Excesos en Canal Once: La directora gana más que el Presidente de la Repu' blica. Emequis. Retrieved from http://goo.gl/yD5GnS

Huerta-Wong J. E. \& Gómez, R. (2013). Concentración y diversidad de los medios de comunicación y las telecomunicaciones en Mé xico. Comunicación y Sociedad, 19, 113-152.

Hughes, S., \& Lawson C. (2004). Propaganda and crony capitalism: Partisan bias in Mexican television news. Latin American Research Review, 39(3), 81-105.

Juárez Escalona C. (2014, October 21). Leyes mejoran condiciones de medios pu’́blicos. El Economista. Retrieved from http://goo.gl/8c7iLQ

LSPREM (2014). Ley del Sistema Público de Radiodifusión del Estado Mexicano. Retrieved from http://goo.gl/I4klEY

Lugo-Ocando, J., Cañizález, A., \& Lohmeier, C. (2010). When PSB is delivered by the 'hand of God': The case of Roman Catholic broadcast networks in Venezuela. International Journal of Media and Cultural Politics, 6(2), 149-167.

Mastrini, G. (2011). Medios pu'blicos y derecho a la comunicación: una aproximación desde Amé rica Latina. In Lecciones del Portal InCom, Instituto de la Comunicación de la UAB. Retrieved from http://goo.gl/pNoqeN

McQuail, D. (1992). Media performance. Mass communication and the public interest. London: Sage.

Mollerup J. (2011). On Public Service Broadcasting and Ombudsmanship. In Professional journalism and self-regulation. New media, old dilemmas in South East Europe and Turkey, París: Unesco. Retrieved from http://goo.gl/y88Wo6

Navarro, F., \& Amézquita,I. (2007, September 13). El Defensor de la Audiencia. El caso del Canal Once”, Paper presented at the Primer Seminario Itinerante de Autorregulación y Medios de Servicio Público, México City. Retrieved from http://goo.gl/w0QlVx

Once TV México (2015). Canal Once. Un joven de 56 años que se mantiene a la vanguardia con calidad total. Retrieved from Once TV México http://goo.gl/AGZhPZ

Ortega, P. (2009). La otra televisión $n$ : ¿por qué no tenemos televisión pu’blica? Mé xico City: Universidad Autón noma Metropolitana, Unidad Xochimilco.

Ortega, P. (2014, November). Alcance y Limitaciones del Sistema Público de Radiodifusión del Estado Mexicano. Observacom. Retrieved from http://goo.gl/tiA32g

Parametría (2015a, October-January). Reporte de Resultados. Evaluación nel Instituto Mexicano de la Radio. Retrieved from http://goo.gl/XIe9vN

Parametría (2015b, June). Conocimiento y opinio'n de televisoras en México. Retrieved from http://goo.gl/494dHW

Rebeil, M. A. (1988). Sistemas televisivos regionales: los inicios de la independencia del centralismo. In Las redes de Televisa. Mexico City: Claves Latinoamericanas.

Rosas T. (2012, September 17). Lanzan nueve señales digitales del IMER. El Economista. Retrieved from http://goo.gl/uyPLV2

Safar, E., \& Pasquali, A. (2006). La radiotelevisión pública en Venezuela. In Radiotelevisión de servicio público: un manual de mejores prácticas, San José de Costa Rica: UNESCO. Retrieved from http://goo.gl/1OIsvn 
Solís, B., \& Calleja, A. (2005), Con permiso. La radio comunitaria en México. Mexico City: AmarcAmedi-Friedrich Ebert Stiftung.

Sosa Plata G. (2014, December 2). Pros y contras de la creación del Consejo Ciudadano del Sistema Público de Radiodifusión del Estado Mexicano. Radio Educación, Retrieved from http://goo.gl/BHnNBd

Sosa Plata G. (2014b, December 1st). Medios públicos: más con menos en 2015. El Universal. Retrieved from http://goo.gl/PYjVUH

Torres, I. (2015). Aportes para la historia de la radiodifusión como servicio público: El Sodre de Uruguay: una propuesta innovadora en el contexto hispanoamericano. Questión, Revista Especializada de Periodismo y Comunicación, 1(46). Retrieved from http://goo.gl/0V3kYw

Toussaints, F. (2009). Historia y politicas de television publica en México. Revista Mexicana de Ciencias Politicas y Sociales, vol. LI, num. 206. Retrieved from http://goo.gl/DteTtM

Toussaints, F. (2009b). La televisión pública en México. Directorio y diagno stico 2007-2008. Mé xico City: Plaza y Valde's Editores.

Toussaints, F. (2010, September 10). Public service media's policy: The cases of México, Venezuela and Brazil in the frame of Europe and Latin America's model. Paper prepared for delivery at $R e-$ Visionary Interpretations of the Public Service Broadcasting (RIPE) bi-annual conference, London, UK.

Trejo, R. (2011, July). Quie' nes, cua' ntos y en do' nde controlan la televisión Mexicana. Zo'calo. Retrieved from https://goo.gl/Sv8Q1u

Villamil, J. (2015, June 22). Denuncian censura y "acoso editorial” en Canal 22. Proceso. Retrieved from http://goo.gl/lh8OcO

Waisbord S., \& G. Mastrini (2015). Principios y”buenas prácticas" para los medios públicos en América Latina. In Cuadernos de Discusión de Comunicación e Información 3. París: UNESCO. Retrieved from http://goo.gl/lwDa6y

Waisbord, S. (2013). Vox Populista, Medios, periodismo y democracia. Bueno Aires: Gedisa.

Yglesias M., \& Velázquez, E. (2015, July 31). TV UNAM, una década de grandes logros. Etcétera, 31 July. Retrieved from http://goo.gl/9PTa9e 
